\title{
Between Mandala and World Stage: A Historiographical Study of a Public Space
}

\author{
Urmi Sengupta
}

Cities change. A sudden natural disaster may destroy a city. Spaces that were once important for the citizens and political life may be lost to development. Spaces that survive hold the quirks of history, culture, and society. This article develops a historical account of urban public space that explores the changing relationship between space, political order, identity, and memory. Using Tundikhel, the largest public open space of national significance in Kathmandu, Nepal, the article takes a journey from the ancient era to medieval times, and right through to the modern period to decipher the ways in which the public space has been historically formed, construed, and interpreted. The main body of the paper explores Tundikhel's evolution through four thematic phases: (1) abstraction, folklore, and mysticism (300-1200 AD); (2) art, mandala and mercantalism (1201-1767 AD); (3) power, visibility, and modernity (1768-1989 AD) and; (4) breaking barriers and emancipation (1990 onwards). The article argues that a post- modern, hybrid nature of the public space today does more to capture the nature of the city's change as a complex, multi-layered shift in which the history cannot be simply erased, but returns to disrupt contemporary narratives of the national space.

Keywords: Public Space; History; Urban; Mandala; Kathmandu 


\section{Introduction}

Cities change. A sudden natural disaster may destroy a city. New regimes may bring new political philosophies. Spaces that were once important for the citizens and political life may be lost to development. A much-loved space may turn into wilderness covered in overgrown grasses. Spaces that survive hold the quirks of history, culture, and society. Tundikhel in Kathmandu is one such space. It is the largest open space located at the center of Kathmandu with a rich tapestry of history closely linked with the city and its heritage. Since the ancient period, Kathmandu has been the foci for empires and local elites. Various kings and dynasties (such as Licchabis, Mallas, Ranas, and Shahs lately) have contributed to the city's spectacular art and architecture, planning and layout, and Tundikhel has remained one of the most enduring and remarkable embodiments of that process. The ancient and medieval planning traditions in the city focused on the cosmic model, religious practices, and the political and religious agendas of the rulers dictating the nature, functions, and spatiality of this space. Rana and Shah dynasties focused on the top down political and communal dimensions of Tundikhel. More recently, Tundikhel provided a platform for two civil wars, popularly known as Jana Andolan, and the subsequent political upheavals (associated with anti-monarchy sentiments). In an apparent reversal of roles, the space was re-defined and re-appropriated from the bottom up. Today, this urban space is a highly regulated and contested site, through (rather controversial) planning and city development processes with wider ramifications leading to rupturing ${ }^{1}$ and shrinkages (Sengupta 2018).

Tundikhel played an important role in Nepal's modern history, and the events and demonstrations that took place were not the first to politicize the space. Its role in the development of nationalist discourses in Nepal as a venue of main historical events took roots even before the notion of nationalism became a valid political subject at the end of the 20th century. The evolution of this space during different phases of history and the meanings ascribed to this space contributed to elevating it to the 'national' stage. This conceptualization primarily stems from the political representation associated with the space. How prevailing powers organize space to communicate sets of meanings are linked to political visions and nationalist ideals. In literature several studies have discussed the relationship between political order and urban space (Bell 1999; Whelan 2001; Mitchell 2000; Light and Young 2010). Other scholars have advanced the notions of space being instrumental for national identity (Anderson 2006) and for making and remaking of public memory (Johnson
2004) alluding to the overlapping meanings of political and social, historical and contemporary, necessitating the study of space to be informed by understanding of culture and society within the historical timeframe.

Making a conjunction of nationalism and urban space therefore must take account of the social and cultural realities. Spaces evolve not just to serve the political goals, but also through cultural and social actions. This conceptualization has been explored by a number of thinkers (Lefebvre 1969; de Certeau 1984; Tuan 1977; Soja 1995 ) who discuss differential embodiment of space as a political and spatial practice. In other words, within the ongoing struggles, tensions, and interactions that are born out of the socio-spatial dialectic, citizens conceptualize space imbued with ideas and knowledges and cultural orientations. Material space (land) thus becomes conceptual space through both the public discourses about it and public experiences ingrained in history. The mutual entanglement of space, society, and culture on a given space is illustrated by the creation of specific functions offering a new rhythm and pattern of activities, over time throughout history.

Historically, an exploration of (cultural) heritage in Kathmandu has been largely monument-focussed (Tiwari et al 2018) obscuring the importance of open space and other features of distinction. Such a skewed perspective not only directs attention to the monumental elements of the city at the expense of others, it also tends to turn the creation of urban form into a series of historically-documented planned acts associated with the building (or rebuilding) of individual structures or building complexes. Modern day scholars' fixation with the city's temples and palaces exponentially grew with the UNESCO's 1979 declaration of seven monument zones in the Valley collectively as a single site, called the Kathmandu Valley World Heritage Site, which placed much focus on the spectacular art and architecture of the city. The scholarly 'amnesia' over space is striking. This in turn created an impression of city development as something large-scale and episodic, obscuring parallel processes which operate on a smaller scale, at a local level and at a slower pace. Writing in Himal, Onta (1991) asserts historians (both Nepali and non-Nepali) are guilty of "disciplinary history writing" with the persistent focus on the rulers and excluding myths and legends that cannot be proved, and in this sense a substantial chunk of history remains unwritten and unrecognised.

This paper attempts to fill that gap by reading Tundikhel and offering some reflections on its historical evolution 
as an important space that shaped the history and in turn, was shaped by history. How this 'space' evolved and what meanings and symbolism were assigned to Tundikhel during different phases of history including how it exists today are the two questions I seek to answer through this paper. In particular, I ask how each political change to the physical, the functional, and the symbolic landscape of the space has been reshaped to accord with the prevailing values of the time. However, the space is also marked by the persistence of signs and symbolisms from previous eras. It therefore becomes an ideal case study through which to explore the changing relationships between space, political order, identity, and memory. To achieve this aim, the paper takes a journey from the ancient era to medieval times right through to the modern period to decipher the ways in which Tundikhel has been historically formed, construed, and interpreted. The main body of the paper explores Tundikhel's evolution through four thematic phases: (1) abstraction, folklore, and mysticism (300-1200 AD); (2) art, mandala and mercantalism (12011767 AD); (3) power, visibility, and modernity (1768-1989 AD) and; (4) breaking barriers and emancipation (1990 onwards).

The paper covers a long period in history, which is necessitated by the the simple, though crucial recognition that the space itself is produced and shaped through evolving and competing political, social, and cultural activities in history. The four thematic phases broadly correlate with important junctures in the city's political history - mainly regime changes - which had an impact on the societal and religious orientation that permeated through laws and regulations including how the space is used. These themes also reflect the social and historical factors specific to those periods, with the symbols and meanings from each successive historical period transcending across different time zones to mediate the relationships between space, power, identity and memory. Space is not relatively simple physical space. The first problem then, as asserted by Rappoport (1970), is in the difficulty of defining space or rather deciding the kind of a space with which we are concerned and second, in trying to produce the complete or meaningful catalogue of meanings of space. In ascribing differential meanings, functions, and spatial contours of Tundikhel through different time zones, a key line of inquiry is to bring out a sense of latent 'nationalism' in the space use, that binds diverse uses together - historically articulated through meanings enforced from top down, and recently, reinscribing through bottom up, thereby converting the space from a site of power to the one of resistance.

\section{The Space, City, and History}

Kathmandu, the capital city of Nepal, is regarded as the country's cultural center, not just because of its geopolitical position but also because its history has influenced the development of the whole of Nepalese civilization (Gabriel 1997). The orderly, disciplined, and planned forms of the three core cities of Kathmandu Valley Kathmandu, Bhaktapur, and Patan - bear the testimony to the sophisticated urban culture and a strict hierarchical city administration. There have a been a flurry of studies on the History of Nepal in the $18^{\text {th }}$ and $19^{\text {th }}$ centuries by British historians (Levi 1905) within which, in the stricter sense, considerable attention has been given to Nepal's relations with British India and with China and Tibet. More recent literatures (Levy 1991; Slusser 1979; Stoddard 1979; Toffin 1990; Oldfield 1984) have shown proclivity to studying the city's builtform and spaces as the city's medieval urban culture remained seemingly irresistible to Western scholars who admired the mystic, deep, religious, and cultural roots of the city (Sengupta and Bhattarai 2016: 94). Local scholars (Regmi 1965; Amatya 1991, 1996, 2011; Pant and Funo 2005; Tiwari 2001, 2002; Gustchow and Bajracharya 1977) have concentrated on straightforward historical narrative and on the publication of indigenous materials to supplement the western records, which remain the most important source.

Historians asserts the early history of Kathmandu Valley is legendary and obscure (Malla 2001; Regmi, 1982). Studies of ancient or medieval historical cultures and their formations have fallen short of reconstructing history due to limited archaeological evidence in Kathmandu. Puratwtwa Bibhag (or Department of Archaeology), a government agency was established only in 1953 following sustained pressure from international agencies. This contrasts sharply with the Asiatic Society of Bengal (1781) and Archaeological Survey of India (1861), both established a few hundred years ago. The Ancient Monument Preservation Act, 2013 (enacted in 1956) vested prerogative powers to conduct archaeological explorations, but, very little as a way of archaeological digging is actually done. The Department's focus has been on preservation rather than pursuing any new lines of inquiry. Whilst the archaeological excavations at a couple of sites have not lent any evidence datable beyond the early centuries (Deo 1968), absence of maps have been equally striking. According to Gutschow and Kreutzmann (2013), the first map of the valley was made by Charles Crawford (1760-1836) who was appointed commander of the escort to the embassy of Nepaul. Crawford's Map of 'Nepaul' was the first scaled map which gives an impression of the overall 'Maps of 
Nepaul Territories.' The technical and scientific mapping of the city started with institutionalization of town planning at the end of the 1960s. Archaeologists or architects would, therefore, have no way to verify the conjectures and theories regarding ancient city plans in the absence of any hard evidence or spatial records. One such reconstruction attempt led Pant and Funo (2005) to hypothesize that similarities exist between other Indian ancient cities and Kathmandu. They found a striking resemblance in the street patterns and block plans of Mohenjodaro, Sirkap (a settlement in the early historic city of Taxila) and Thimi in Kathmandu Valley. Both cities appeared to use similar measurements and modular dimensions of 19.2 meters (a length equivalent to one rajju of ancient times) in their visions of the settlement blocks. Pant and Funo further confirm the employment of danda and rajju in the planning of the city of Patan. Both units are incidentally mentioned in Kautaliya's Arthashastra from $4^{\text {th }}$ century BC as a utopian template for town planning from ancient Vedic culture. Nepal's reference in Kautilya's Arthashastra - a collection of gnomic verses of Chanakya which is suggestive of a close cultural relationship with Indian cities and by implication, substantial knowledge-transfer in city planning and design may have been possible. Regmi (1965: 11) considers the date of this document to be a period earlier to the Christian era, which brings Nepal closer to ancient cities in chronological terms. Further references of connection to ancient Indian cities can be found. For instance, one local interpretation for the origin of Nepal suggests the city to have been founded by a saint named 'Ne' who is also credited to have been the founder of the powerful Gupta empire in North India (Levi 1905) around the same time. Despite such potentially illuminating parallels and contrasts, Nepali history has tended to remain a relatively isolated study, not forming part of the main current of South Asian historiography, although anthropologists adopting an historical perspective have made useful attempts to fit Nepal into the wider framework of Hindu polity, most significant being the work of Levi (1905) on the idea that Nepal is to some extent a microcosm of the whole Indian subcontinent ${ }^{3}$. It is important to recognize that in historical narratives, rarely one finds reference of Kathmandu, and instead, most accounts refer to Nepal while discussing Kathmandu. These accounts indicate high-level analysis that rarely go into the specific details of spaces and buildings.

Urban space as a phenomenon in its own right is addressed only selectively by modern day scholars and there is a persistent focus on the role of monuments in shaping the city. Amatya (1996) in his book Monuments around Tundikhel, for example, uses Tundikhel as a setting for the landmarks rather than making it an object of the study per se. The corollary to this view suggests public space such as Tundikhel is not considered as heritage nor understood on its own terms, but rather is seen as an extension to the built form and everyday practices relegating it to the margins of history. In terms of town planning, this central space may or may not have been consciously designed or had a rigid framework of its evolution. Tundikhel may have grown over time, by a process of accretion and overlay and perhaps did not result from a single grand design. The only reference to Tundikhel's size and scale is found in Tri Ratna Soundarya Gatha, which suggests the space was roughly 2-3 miles long and 300 yards wide, its boundary stretching from Dasharath Stadium on the South to Jamal to the north, Durbar Square to the west, and Tukucha River to the South. With the exception of the encroachment on the eastern and southern end, Tundhikel's broad spatial disposition as described in this Gatha remains today. The document is a text written by a Buddhist monk Pundit Sundaranada Banda in the 1st half of 19th century comprising formidable historical record on different aspects of Nepal in the centuries immediately preceding it. It is not possible, however, to verify the veracity of this document or how far back in chronological terms it could realistically go.

Nevertheless, the absence of hard evidence requires us to look for alternative sources of knowledge such as anecdotal evidence, narratives, and stories to explain Tundikhel's significance. History ultimately, Ethington (2005) claims, is cartographic as well as narrative. The challenge is how to tell stories that bring space and time together into a coherent whole. Tundikhel as a 'space' has seen repeated mentions in historical narratives, religious scripts, folklores, and stories. When carefully put together, such information makes up a cumulative body of knowledge, practices, and representations. By relying on these sources, it may be possible to obtain a better understanding of the role, which Tundikhel played in the development of Kathmandu's society and culture.

Scholars ${ }^{4}$ have detailed out the constructed-ness of history in evolution, plans, and formations of ancient cities. Among those, Rapoport's (1990) work on the meanings of the built environment is useful for approaching historical narratives that help to draw out the conception and the meaning of public space. According to Rapoport, meaning links environments and people by providing much of the rationale for the ways in which environments are shaped and used. He also believes that meaning is not only part of the function, but is often the most important function of the built environment. Rapoport distinguishes three levels 
Table 1: Conceptualization of Tundikhel

\begin{tabular}{|l|l|l|l|}
\hline Dominant theme & Era /Dynasty & Period & $\begin{array}{l}\text { Built environment meaning } \\
\text { (adapted from Rapoport) }\end{array}$ \\
\hline Early settlement formation & Kirat & $-360 \mathrm{AD}$ & Unknown \\
\hline Abstraction, folklore, and mysticism & Licchabi & $361-879 \mathrm{AD}$ & High \\
\hline & Thakuri & $880-1200 \mathrm{AD}$ & High \\
\hline Art, mandala, and intellectualism & Malla & $1201-1767 \mathrm{AD}$ & High/Medium \\
\hline Power, visibility, and modernity & Shah/Rana & $1768-1951 \mathrm{AD}$ & Medium/Low \\
\hline & Shah & $1952-1989 \mathrm{AD}$ & Low \\
\hline Breaking barriers and emancipation & Republicanism & $1990 \mathrm{AD}-$ & Low \\
\hline
\end{tabular}

Source: Compiled by Author

of meaning in the built environment. According to him a high-level meaning describes cosmological and supernatural, symbolism, that may be encoded to buildings or city layouts; middle-level meaning refers to deliberate messages about identity and status communicated by the designers and low-level meaning describes in which the built environment channels and interacts recursively with behavior and movement.

Rapoport's three levels of meaning in the built environment provide a particularly useful framework for studying the origin and evolution of the built environment for Kathmandu that has a number of historical layers underpinning its evolution. To apply his model, we assign Tundikhel's history into different major and minor development phases in chronological order (Table 1) of which this paper primarily focuses on the four main thematic phases: (1) cosmological origin of the city and its spaces (2) the mandala and mercantilism focus of the medieval era, (3) political and social significance of the Shah and Rana period and (4) contestation and emancipation since the 1990. The boundaries between levels of meanings remain much more fluid and flexible however. Smith (2007) when reflecting on the work of Rapoport, points out that it is possible for all three meanings to be expressed and construed in relative importance. He contends that cities, buildings, and urban features typically communicated messages on two or three levels, and it can be difficult today to determine the relative importance of the various levels of meaning. In other words, a number of the architectural manifestations of cosmological (high level) meaning are usually best viewed as expressions of middle-level meaning. An argument could, therefore, be made that they actually are interconnected and inform one another.
In the following section, I examine four thematic phases from history that describe the evolution and development of Tundikhel.

\section{Abstraction, folklore, and mysticism (300-1200 AD)}

I use abstraction and mysticism as a historical narrative and a starting point to trace the spatial and cultural identity of Tundikhel. The complex and sometimes contradictory cultural formation of the mystical, myths, and folklores nonetheless provide a reference point for the understanding of public spaces especially in the absence of any historical record. Even when records do exist, both Rapoport (1970) and Gramsci (1997) encourage the use of folklores, oral traditions, and myths to contest 'official' conceptions of the world. Rapoport (1970) argues that one needs to know the ideal in order to know the visible order - for example sacred directions and sacred prototypes. This may require anthropological research or travel descriptions and also description of how such space was used. An early articulation of Tundikhel's origin and evolution in ancient Kathmandu leads us to cast wilful eyes at the patterns of interaction between the society and space, imaginary as well as real. In ancient history, more than buildings or structures, public space provides the requisite background to such stories, and as the central body thus making it both a canvas and subject.

Owing to the unique mix of Hindu and Buddhist religion, it is logical to conjecture their influence in the conceptualization of public spaces in Kathmandu in general and Tundikhel in particular. After all, religious beliefs encompassed rules for every aspect of daily life. According to Shilparatn ${ }^{5}$ - a Hindu scripture for art - gardens/open spaces were either the royal gardens (Nep. Pramodavana) 
or the public gardens (Nep. Nagaropavna) located outside the town for health, recreation and enjoyment of the town dwellers. From its location relative to the city, Tundikhel was perhaps conceived as the latter. As a parallel, Singh (1976) has traced the specific lines of historical influence of Buddhist scriptures on public parks in ancient planning ${ }^{6}$. He cites (ibid: 374) Digha Nikaya $a^{7}$ to assert that Buddha dwelt at Rajagriha of Ambabhavan located in Vaishali (present day Bihar) and owned by the royal physician called Jivaka. According to stories and folklores, Vaishali was full of parks and gardens. The Tibetan Dulva (or Vinayapitaka - considered the most unquestionable scripture originating from ancient Tibet) describes the city as a kind of earthly paradise. Many of Buddha's immortal discourses were delivered either in AmbaPalivana (mango groves of Ambapali) given as a gift to Buddha from a courtesan name Ambapali in the outskirts of the city or in the pinnacle hall Mahavan (Kutagavasala) - the great forest stretching up to Himalayas, both celebrated public gardens. The city of Vaishali was ruled by a powerful Licchavi dynasty, a splinter of which went on to rule Nepal some five hundred years later.

The Buddhist connection of the Licchabi Clan and their close alliance with Tibet is credible evidence of Tundikhel's conceptualization as Promodvana. The concept of Promodvana in a slightly different form manifested during both Malla and Rana era, when the use of the Tundikhel for various jatras and festivals began (such as Ghode Jatra). These events/performances were primarily witnessed by the rulers, and thus carries the mantle of being predominantly a leisure use. The 'leisure' use appears to be a consistent factor through either 'sacredness' in the pre-medieval periods or jatras and festivals during Malla and Rana period to decipher Tundikhel's role as Promodvana.

Among the early narratives available in the vast archive of textual collections in Kathmandu, the origin of Mahankal Sthan provides a special provenance and another important reference point for Tundikhel's Buddhist link, its location and relative importance in the city. Mahankal (Mahakala in the ancient world) is a popular deity revered by Hindus and Buddhists both. The temple is situated at Tundikhel, although the construction of the perimeter roads in the late $19^{\text {th }}$ century put it just outside of Tundikhel's western boundary (Figure 1). The origin of the temple is not clearly known, however, Lewis (1989) gives an account that the deity's Himalayan abode was Tibet, most probably evolved from the Indic Shiva-Bhairava, and later Buddhists incorporated this fierce deity in their pantheon. The depiction of this folklore can still be found in the four copper plates of the walls of Itum Bahal monastery, which goes as:

There once dwelt in Mantrasiddhi Mahavihara, the present Sabal Baha, a Vajracarya named Saswat Bajra. One day he was sitting in the sun after an oil massage and just then a cloud mass came floating by in the sky, cutting off the sunlight. When Saswat Bajra looked up, he saw that the cloud remained stationary. Then he went out of the Vihara to Aganchapa, the present Tundikhel, and mediated with the purpose of bringing down the cloud to him. He succeeded and went to the place where the cloud had landed. He saw the deity Mahakala inside the cloud and discovered that he was on his way from Lhasa to Kasi. Then Saswat Bajra performed puja to Mahakala and chanted the "Panca Kapal Acarya," a song of his own composition. When this puja was over, Mahakala blessed Saswat Bajra, agreed to be present on Saturdays for offering at this site, then disappeared into the sky (45).

Myths have always attained archetypal dimensions in Nepalese consciousness diagonally cutting the cultural and spatial context of Kathmandu. Gutschow and Kreutzmann (2013) remind us in discussing the Hindu and Buddhist myths of the creation of the valley that the history of Kathmandu is all about extolling the deeds of kings, ascetics, and saints, and testimony of their meritorious acts abound. According to one such myth from the $12^{\text {th }}$ century, a mythical creature called Gurumapa kidnapped disobedient children and ate them. After several incidents of disappearing children from the valley, the local residents promised Gurumapa to provide an annual feast if he left the neighborhood and moved away to Tinkhya (Tundikhel) - the vast open space in the periphery, roughly a mile or so from the core, taking Durbar square as the nucleus. The explanation here first entwines the 'physical space' with the 'mythic space' giving new interpretations and at least a cue about the location of Tundikhel.

Tri Ratna Soundarya Gath $a^{8}$ provides further clues on the specifics of ancient symbolism and beliefs to articulate in tangible forms. According to this ancient text (which existed for centuries but only written in early $19^{\text {th }}$ century), Pratyagira devi and Bajrabhairab donated this land to their daughter Vajratundi in dowry, which gives the place its name 'Tundi'. In ancient Buddhist scriptures, Tundikhel was called 'Angachapa' interpreted as "Tungkhyo" in Newari - which means open space water. The place was a large Marshland in ancient times, and the connection to water is consistent with Kathmandu's origin by draining out a lake. Overtime, Tunkhyo changed 
into Tinkhya, which means a playground in the local Newari dialect. The closeness of the names 'Tungkhyo' and 'Tinkhya' certainly suggests, at the very least in linguistic terms transformation of Tundikel into more vibrant place supported by limited but important epigraphical record. The inscriptions found in Mahankal temple suggest that it was part of a much larger temple complex fashioned in Buddhist Vihara, originating from Licchabi era. Some remnants of the idols of Vishnu and Saraswati found scattered in Tundikhel were brought and installed in the eastern and western walls of the temple in 1960.

Underpinning these popular folklores and the spatial context that evolved indicates Rapoport's high-level meaning influencing the origin and evolution of Tundikhel. In particular, in the construction of Tundikhle, the society then follows an imagined societal projection of its desires, rather than conceptualizing space through localized customs and rituals. This shift in focus introduced a new complexity into the symbolic space of the space. The story of Gurumapa re-established this space as a place of national as opposed to local memory which would later morph into Tundikhel's role as a national space for display of power and might and for national announcements. The prevalence of three important temples in and around Tundikhel and the linguistic evolution from 'Tungkya' to 'Tinkhya' lend sufficient realism to the space being locally for recreation and sports use. On a wider scale, these narratives confirm the importance of what Holloway (2006) calls the sensuous, vitalistic, and affectual forces through which spaces of the religious, spiritual, and the sacred are performed. They also elucidate how religious-sacred spaces (re)produce societal and cultural transformation.

\section{Art, Mandala, and Mercantalism (1201-1767 AD)}

Tundikhel legend during the medieval period signifies an outcome of an interweaving of several historical concepts among which the mandala dimension stands out. According to Gutschow and Bajracharya (1977), Kathmandu was systematically conceived as a mandala. The late Nepalese historian, Dhanavajra Vajracharya believed that the ancient State of Nepal was almost as big as modern Nepal, and that the mandala model was applied to the whole country and was called 'Nepala Mandala.' That claim may appear far-fetched, but according to the ancient Sanskrit text Manishaila Mahavadana, Jogdev created eight shrines of the mother goddesses (Astamatrka pitha) inside the town and eight outside based on mandala principles. It is said that Astamatrika (the nine female powers in Hinduism such as Kumari, Nilakali Chamunda,
Nilabhairavi, Rudrayani, Vaishanavi, Maheshwari, Indrayani, Swetbhairavi, Brahmani, Ganesh Vairabhi) was established, who are propitiated and worshiped as an invocation for protection from the natural forces that threaten the agricultural cycle as well as from forces that threaten the moral order of the city (Levy 1990). These shrines of the mother goddesses (Nep. pitha) which governed the city's form, still exist in the places mentioned in the Manishaila Mahavadana. The traces of abstract mandalas can also be mapped, stretched out into real urban patterns, in cities like Kirtipur (Kostof 1999) and Sankhu (Sharma 1996) in more articulated and consistent ways than bigger cities such as Bhaktapur or Kathmandu.

It must be noted that scholars have taken the mandala origin with their own often subjective justifications. Gutschow and Bajracharya (1977) suggest that during Malla period, a grid pattern was superimposed with the ancient mandala art which dictated the ensuing spatial disposition. ${ }^{9}$ Stoddard (1979) claims the arrangement of sites that resembles the geometric configuration of a mandala does occur repeatedly in the Kathmandu valley at various scales but dismisses the idea of having one mandala covering the whole city. He asserts: "in the ideal form, sets of sacred places are situated around a central position in the same pattern as geometric figures surround the center of a mandala" (ibid: 104). Arhana (1991: 33) claims that mandala reflects hierarchical arrangements for deities with Bramha taking up the central squares or the shunya sthan. Smith (2007: 33) questions the cosmological concepts expressed in city layouts in the absence of detailed historical records. He contends, citing Bhaktapur, a neighboring city, local Brahmins drew an idealized map of the city in the form of a mandala, but this figure bears almost no physical resemblance to the actual city plan. He does, however, accept that it provides a good description of the symbolism of architectural features, the routes of sacred processions, and the religious meaning of the city to its indigenous inhabitants.

"The city is a mandala," claim MacFadyen and Vogt (1977:307) when discussing Kathmandu's sister city Bhaktapur. Mandala is the space where "physical and mythic space interrelate and entwine each other" (ibid: 307). This conceptualization elevates the city and its spaces to bear higher meanings and symbolisms, and on that basis the mandala principle must have permeated into organizational principles of urban layout and planning. It then offers scope for an interesting hypothesis: Is Tundikhel the revered shunya sthan which elevated its status during the medieval times? The answer, however, quite amazingly, is not affirmative. There is no evidence of 


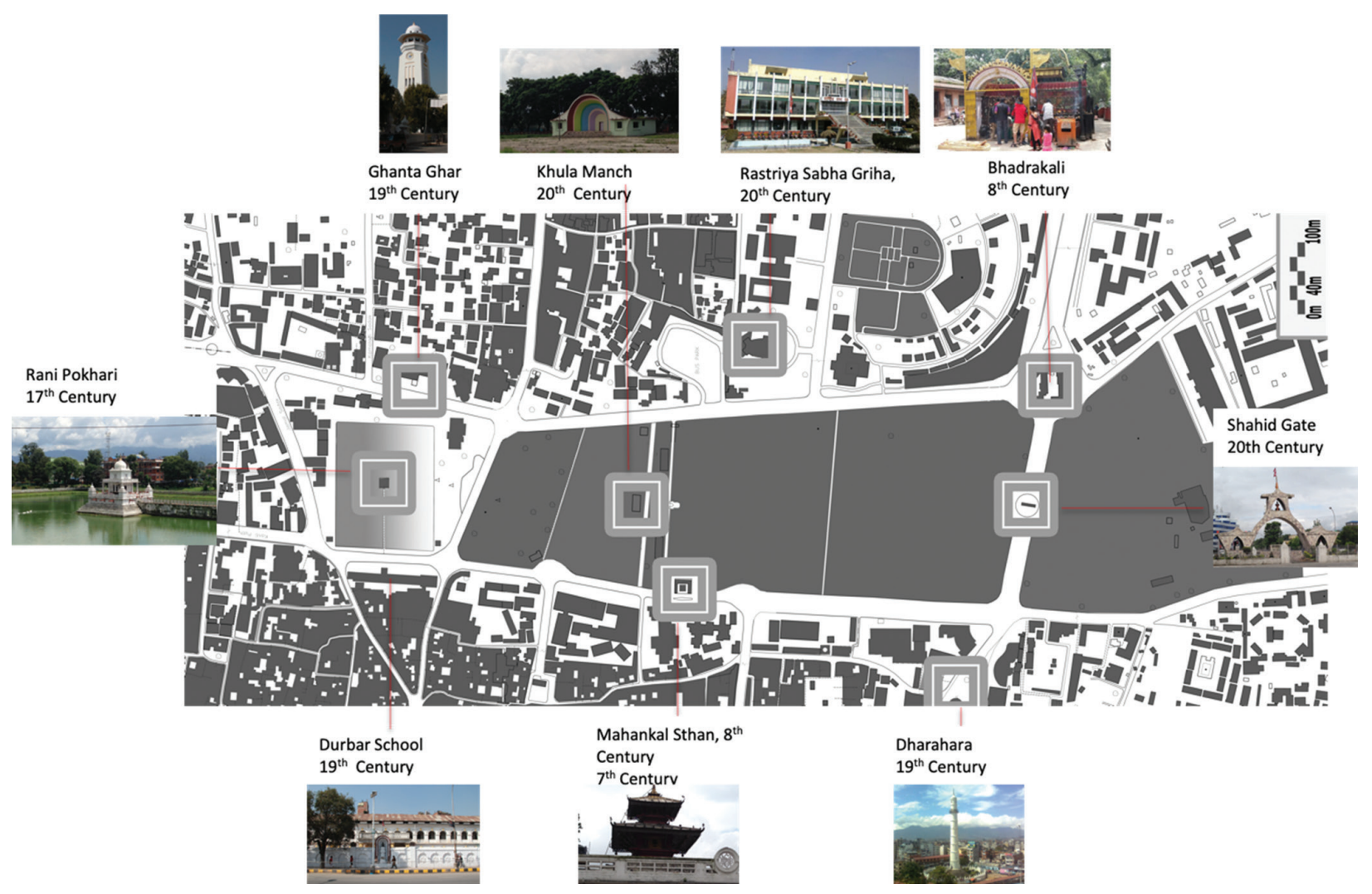

Figure 1: Tundikhel and its Landmarks from Different Phases of History

Source: Author

the centrality of Tundikhel in relation to the spatial order and hierarchy of the historic city. Tundikkhel's location to the east of the city has been established by Oldfield ${ }^{10}$ who refers to the eastern gate opening up to a large open space (Tundikhel). There are several etymological interpretations that back up the eastern location of Tundikhel. In ancient Newari, te means 'east' and reference to the word can be found in both ancient and medieval period inscriptions (Bajracharya (1973), which survives today and still abundantly used locally (such as Teta Dhvaka eastern city gate, Teta Thur (eastern stupa), Tendokhyala - modern Tundikhel Temdo Vihāra (modern Tebahāl, a Buddhist monastery at the eastern section of the old city of Kathmandu). In classical Newari, Tekhu or Tekho 'the Eastern River' is regularly used for the Bagmatī river.

Notwithstanding scholarly scepticism and the eastern location of Tundikhel with respect to the historic city, there is a general agreement on the Astamatrika planning and its associated religious value to be the basis of mandala model. Noted historians such as Slusser (1982) have detailed the cosmological origin of Kathmandu and how cosmological values have influenced our perception of the place in history tracing the origin of the city to the ancient mandala model. On this basis, the possibility of the mandala principle being applied on the wider geography is realistic which makes Tundikhel's centrality to a city in history possible. In the ancient period running up to the end of Licchabi period ( $12^{\text {th }}$ century), the city's central nucleus appears to vary a great deal (Levi 1905). According to the noted historian Sudarshan Raj Tiwari, the ancient town of Devpatan existed near Hattisar, Naxal. Likewise, Sylvain Levi's historical account (1905) shows various rulers in pre-Licchabi era building at various locations. The city of Manjupatan with Bagmati to the east and South; Vishumati to the west; and Shivpuri to the north covered a much larger area than the medieval historic city. Levi (1905) asserts that another ruler, Sudhanvan, transferred the capital to Sanksya (on the banks of Iksumati), current Tukucha that lies east of the current location of Tundikhel. More notionally though, existence of an urban space called Tundikhel in towns in the valley and indeed in many Newar towns and hamlets outside the valley (such 
as Palpa and Bandipur in Western Nepal) brings credibility to assertion that the space may have been part of mandala principle with geographic and topographical variation.

That the mandala principle was ingrained in the development of the city layout and art and architecture during the medieval era puts the city and Tundikhel's historical transgression from Rapoport's high level meaning to middle level meaning, transmitting messages about identity, status, and power. Nepal's strategic location as part of the trade route between Tibet and India was acknowledged in the pre-medieval era which was laid firmly during the reign of Anshuvarma (595-21 AD). The king exercised a clever stroke of diplomacy to maintain the balance of power by marrying his daughter Bhrikuti to the powerful Tibetan King Tsrong Tsong Gyampo. Bhrikuti exercised her good offices in spreading Buddhism in Tibet. Scholars ${ }^{11}$ believe because of her efforts, Buddhism took its root in Tibet and Nepal became a flourishing trading post in the period that followed. Traders from India, China, and Tibet came to Nepal for trading silk, salt, and jewelleries. Enterprising Newars travelled to Tibet as caravan merchants engaged in salt/grains and luxury goods and became a dominant ethnic group to link Tibetan economy with India. The scale of trading activities had been high as Lewis (1989) argues traders set up trade diasporas and stationed their relatives into key trade spots. There was also an increasing transient traffic of Tibetans visiting Kathmandu that required temporary camping ground and bathing places (Frechette 2004). Tundikhel thus became the national economic space and Rani Pokhari as the first site for grandeur and aesthetics to the largely barren Tundikhel for ancient traders until 1904 when Nepal's strong trade relations with Tibet ended with Rana Prime Ministers' growing closeness with East India company.

Rani Pokhari marks a transition from the cosmological theme of earlier era to mercantile theme for the city marked by architectural manifestations of cosmological (high-level) meaning and traits such as grandeur, monumentality, symmetry more usefully viewed as expressions of middle-level meaning. Built by Pratap Malla in 1670 AD to console his bereaved queen who was saddened deeply by the death of their son, ${ }^{12}$ this perfectly squared pond (Figure 1) was created with a Shiva temple at the center and filled with water from various sacred lakes and rivers across India and Nepal, (such as Muktinath, Kedarnath, Ganga, Sapantirtha, and Budhanilkanth), for religious purification purposes followed by statue of himself and elephants in the four corners of the pond. Visibility in ancient cities, Smith (2007) claims, has influenced the design of buildings and spaces as well as the locations of key ceremonial and political activities, which became more prominently applied in the next era. Commemorative memorials, monuments, and statues reify the memory of certain events and individuals within the public arena, which Till (2004: 351) argues represents ruling elites' efforts in creating "material landscapes as stages to display a distinctive national past and articulate an exclusive understanding of a cultural-political community." Rani Pokhari became the first intervention in the recorded history of Tundikhel's transformation. By mixing grandeur with religious sentiments, it constituted re-articulation of the urban space during the period of Nepalese history, when the city's role as a major entrepot linking India and Tibet was at its zenith.

\section{Power, visibility, and modernity (1768-1989 AD)}

The start of the Rana period marks an important milestone in Tundikhel's transformation as a site for displaying might and sight. The mysticism of the earlier period gradually started eroding with the introduction of various monuments and buildings in the periphery of Tundikhel. The city expanded and Tundikhel started to assume a more central location. More importantly, the modern rulers with links to India and Britain brought home new ideas of using the city's open spaces and monuments. When Jung Bahadur Rana (the first Rana Prime Minister) came to power, the army was paraded in Tundikhel, but it was Bhimsen Thapa, who could be credited for the imposition of urban forms in and around Tundikhel, established the hegemony of brave and strong Nepalese army renowned as the Gurkha regiment in the subsequent period. Thapa, as the Commander-in-Chief of the Nepalese army, invited French advisers to train Nepalese soldiers in European military style, and with the help of a strong army he managed to extend Nepal's border to Sutlej river in the west to Teesta river in the east. Most of the territories he acquired, however, were lost in the Anglo-Nepalese War (1814-1816), fought between Nepal and the British East India Company over a territorial and trade dispute. The war ended with a treaty, locally known as Sugauli Sandhi in 1816 and subsequently, one-third of Nepal's territory was given to the then East India Company. Thapa was a brave, shrewd, skilled diplomat and in many ways, saved Nepal from coming under colonial sovereignty.

The militarization of Tundikhel that began with the training of Nepalese soldiers was accompanied by the construction of a number of monuments and buildings and expansion of Tundikhel with trees and landscaping. The construction of the Dharahara tower (1813/1814), which overlooks Tundikhel became the most emboldened 
symbol of military influence on urban forms in the city. The construction of Bag Durbar on the south-eastern edge of the old city (near Durbar Square), Sil Khana in Lagan and Sil Khana in Chhauni (both probably erected between 1815 and 1820) effectively brought soldiers much closer to Tundikhel. Barracks were constructed on the east and north sides of Tundikhel. A foundry was built to manufacture cannons on the south-western side. The army's presence first became apparent with a ritual of firing cannons at Tundikhel every day at noon. So, with the canon came the guardhouse, with the guardhouse came the military, which was the harbinger of the military occupation of substantial parts (now exceeds one-third) of Tundikhel in later years. ${ }^{13}$

Space can be used for rhetorical statements of political identity or state power in different ways. Successive Rana rulers (between 1845-1851 AD) furthered the symbolic significance of Tundikhel beyond the military display by using Tundikhel as a venue for important announcements as well as for hosting stately events that define some of the deeper political and social change in the country. For example, in 1924 Prime Minister Chandra Shamsher (1901-1929) announced the emancipation of slaves under the landmark tree known locally as Khari Ko bot (Figure 2). He had also organized a mass-feeding of the poor and the priestly caste( Nep. Brahmins) at Tundikhel upon returning from Europe in 1909 (Figure 3). Nepal is one of the poorest countries in the world which has always witnessed rapacious aristocracy while denying two meals a day to the majority. It could be assumed that after seeing the prosperous parts of the world, Chandra Shamsher wanted to offer some humanitarian services, rebalancing with some socially acceptable mores and customs, which came alive in Tundilkhel. For example, despite a very short tenure, Deb Shamsher ( $5^{\text {th }}$ March $1901-27^{\text {th }}$ June 1901 ) is credited with introducing the first ever cinema in Nepal. A silent movie was screened in Tundikhel for one week free of charge in 1901 (Maharjan 2010). Some of the black and white photos taken by Dirgha Man Chitrakar (the first photographer of Nepal) give us fascinating glimpses of how Tundikhel was used by Ranas both politically and philanthropically (UNESCO 1997).

Interestingly, important social and political dimensions intertwined with the cultural practices such as Ghode Jatra (horse festival), Rato Macchindranath Ratha Jatra (chariot festival), and Kumari Jatra started taking place

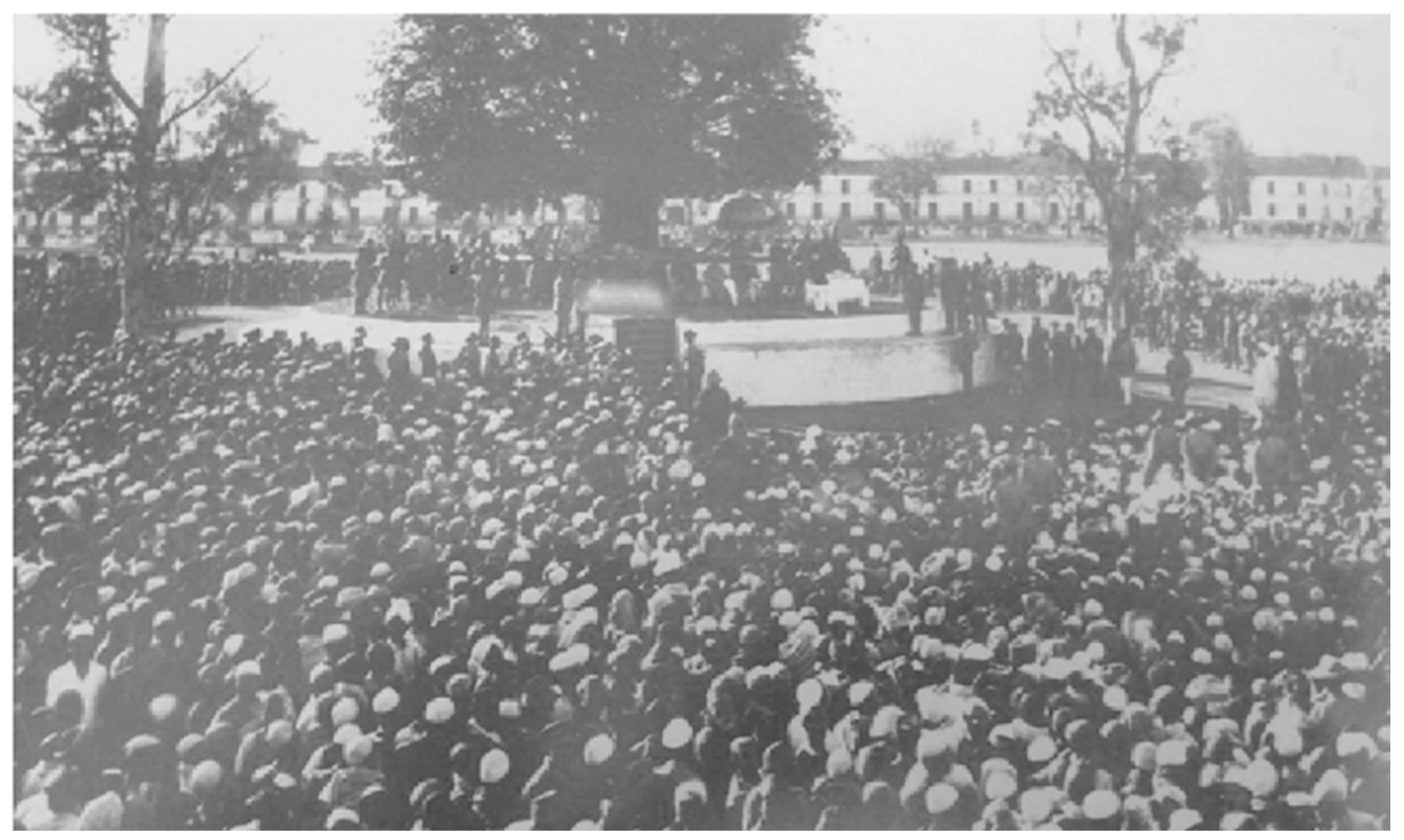

Figure 2: The public proclamation of the end of slavery at the Khariko Bot in Tundikhel, 1910)

Source: Photo taken by Dirgh Man Chitrakar in 1909. See UNESCO Changing faces of Nepal (1997) 


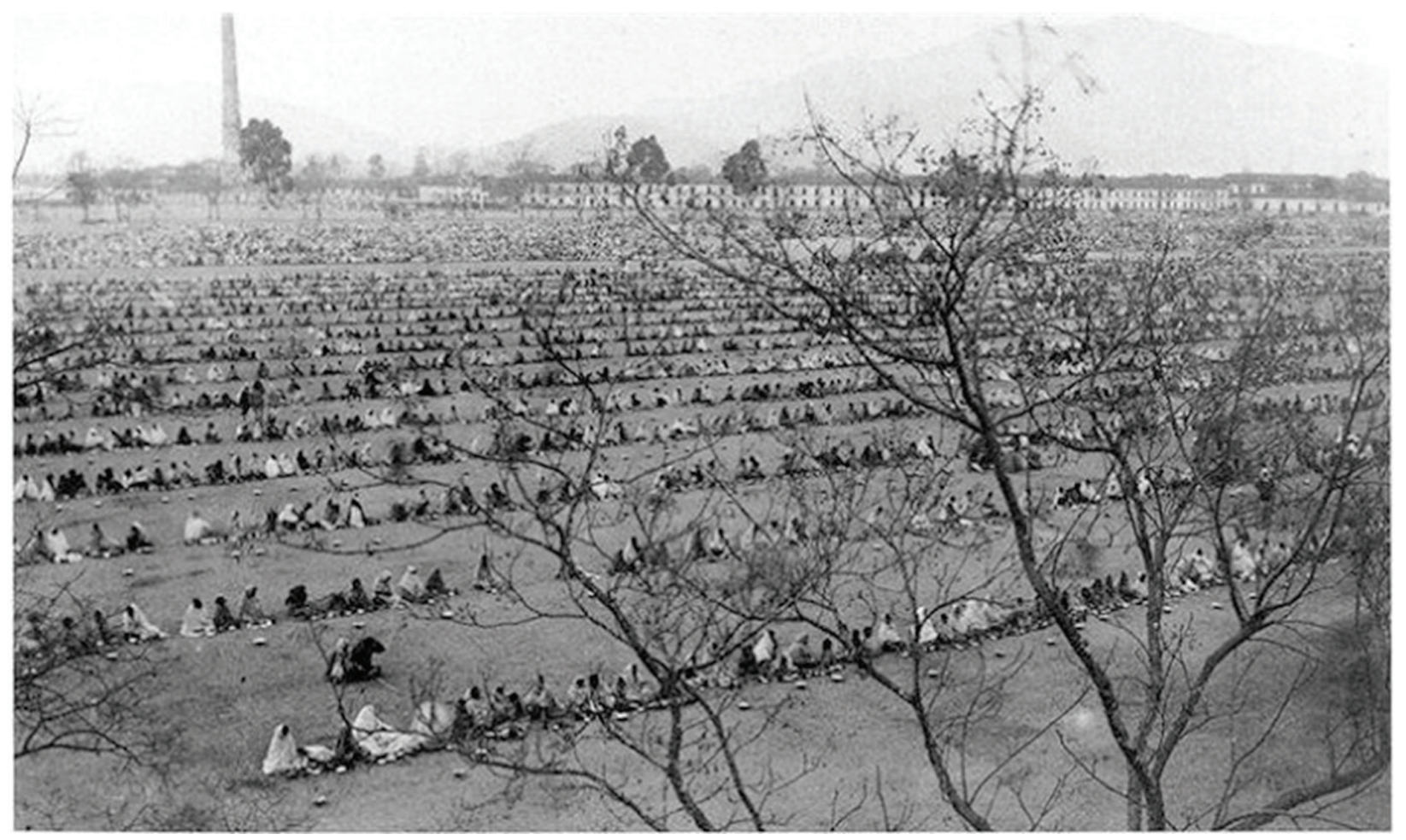

Figure 3: Feeding of the poor at Tundikhel when Prime Minister Chandra Shamsher returned from Europe)

Source: Photo taken by Dirgh Man Chitrakar in 1909. See UNESCO, Changing faces of Nepal (1997)

in Tundikhel often graced by the Royals. The power of the palace was provided with cultural rationales through the co-option of religious festivals by the royal family (Routledge 1994). These activities have not only given new meanings and definitions to Tundikhel, but also helped strengthen user and object relationships. The use of the public space and structures to exercise the power of the state, its control over labor, and the place of commoners within the state show characteristics of Rapoport's middle-level meaning. The military staying very close to the royals was rewarded with the premium parts of Tundikhel which eventually led to the construction of the army headquarters in 1989 in the southeastern corner of Tundikhel. However, the variegated history of Tundikhel suggested it to be not just a 'royal ground,' but, similar to Dovey's account (Dovey 2001) of Sanam Luang (Bangkok), a 'symbolic ground' where all forms of political power, including military and democratic constitutions, needed to honor the Royals to succeed. The powerful political notion that governed this space during Rana regime has prevailed, with the erection of Shahid Gate in 1961, to commemorate the four martyrs executed during Rana regime. ${ }^{14}$
Since landscape is important to the working of ideology and political order, it is hardly surprising that change in political regimes is often accompanied by efforts to remake official public landscapes. The dramatic and widely reported events that accompany revolutionary political change pulling down statues, destroying monuments, and renaming streets are well known (Light and Young 2010). In a recent development, King Tribhuwan's statue was removed from shahid Gate, effectually disconnecting his role from the wider historical narrative of struggles against the Ranas. Whilst the memorials communicate a particular vision in Nepal, their meanings are strongly rooted to a political rather than a cognitive notion of space and time, a legacy of the Rana period. Such counter-establishing of history to influence the public memory played out in a public space has continued right through to the $21^{\text {st }}$ century. For instance, Whitmarsh (2019: 203), referring to the newly constructed Republic Memorial (Nep. Ganatantra Smarak) at Narayanhiti, argues this to be "an attempt to adopt the figure of the martyr and its associated tropes of sacrifice and struggle." Martyrs in this sense are those who sacrificed their lives during the political struggle that quashed monarchy in the recent democratic 
movement. Etched in such attempts, are the repurposing of the national narrative traditionally associated with the key spaces and symbols of national significance. In these accounts emphasis is placed on the discontinuity of urban cultural landscapes of the previous regimes to develop national identities associated with modernity and democracy.

The Rana period also marks an important phase in spatial history with the expansion of the old city of Kathmandu that would eventually bring Tundikhel from its peripheral location to the center of the modern city. Above all, Ranas learned the imperial art of instrumentalizing urban space and monumental architecture for power and dominance leading to the morphological intervention of the space, which has had a lasting impression. Erection of iconic public buildings, and striking examples of architecture or engineering to express agenda and values of ruling elites and their particular ideologies was not uncommon (Mitchell 2000). Rana rulers' fascination with western architecture and their close link with the British Monarchy led to foreign visits that often brought new ideas of building and planning. The first Rana prime minister Jung Bahadur Rana, after his tour to various European countries, initiated the relocation of the palace complex from Durbar Square to the current location, Narayanhiti, followed by the construction of Singha Durbar and Ghantaghar in Victorian architectural style. Ghanta Ghar ${ }^{15}$ (Clock Tower) was built as the residents of Kathmandu had no scientific means of knowing the time and it was completed during the reign of Bir Shamsher (1885-1901). Several other landmarks were built around Tundikhel, among them, Durbar School deserves a special mention. Heralded as Nepal's first school founded originally in 1854 at Thapathali Palace, it was relocated to the newly erected building at Rani Pokhari in 1894 (Figure 1). It became a public school during Prime Minister Bir Shamsher's tenure. The plain, white building stands out due to its simplicity, proportion, and scale and fitting response to Rani Pokhari. The influence of neoclassical architecture is evident with columns on an elevated base and an entablature framing the main entrance of the building. The relocation of Durbar School marks an important trigger point to turn Tundikhel into a civic space of great significance. Institutional buildings such as Jama Masjid Mosque (1774), Bir Hospital (1890), and Trichandra Campus (1918) were constructed, which framed Tundikhel's boundaries in the subsequent period. Each demonstrated a marked rejection of Kathmandu's traditional architectural style and a tabula rasa approach.

The exercise of power through iconic buidings continued in the post-Rana regime (post-1951) also marks an important phase in spatial history with the expansion of the old city of Kathmandu. Subsequent spatial progression saw new landmarks with civilian significance added to both sides of Tundikhel such as Dashrath Stadium (1956), the Rashtriya Sabha Griha or the City Hall (1967) and Ratna Park (1965). The historical Ratna Bus Park turned Tundikhel into the first transport hub in the city with Tundikhel the first point of arrival and ensuring first impression. The country's opening up to the outside world coincided with the advent of motor cars in the city leading to the construction of two arterial roads - Shukra Path and Dharma Path which now flank Tundikhel, linking Singh Darbar with Narayanhiti Durbar. These roads effectively confined the limits of Tundikhel such that no further expansion could be possible but provided the geometry for the shape and form that exist today. The rectangular form received renewed emphasis through the construction of wider roads and sidewalks after the catastrophic earthquake in 1934 which destroyed most of the buildings in the valley, killed more than 10,000 people and injured countless others. Thousands of people took shelter in the Tundikhel ground for months after the 1934 quake. History repeated once again with April 2015 earthquake. This highlighted the importance of Tundikhel's role as a central open space of great significance.

\section{Breaking barriers and emancipation (1990 onwards)}

Through the historical antecedents, the preceding paragraphs demonstrate that Tundikhel bears a testimony of resilience and adaptability arising from the prevailing religious, social, and political context of the city during different phases of history. Plausible arguments can, therefore, be made to show how Rapoport's meanings come into interplay across different periods with varied spatial manifestations. The establishment of temples at Tundikhel during the early Licchabi period is suggestive of the cosmological and symbolic significance of the space which was crystallized through mandala planning and layout during the medieval period. Tundikhel's role as a site for the military display of power and pride became prominent during Shah and Rana period which reaffirmed the supremacy of the rulers, thus intertwining Rapoport's a middle- and low-level meaning. The difference in these meanings reflects the different conceptualization of space - but only to a degree. They also reflect a coherent force of cultural and social traditions prevalent through antiquity to today.

These historical insights offer up a set of themes that may be useful in understanding Tundikhel's emerging new role in the national and world stage as a point of 
collective signs and symbols, accommodating a broad array of activities and possibilities. A key theme emerging relates to assemblage owing to respective visions from the rulers of different era. Yet, at the same time citizens (increasingly) contest, redefine, and appropriate the space. This has been most apparent during the civil war that saw Tundikhel playing a role similar to that of Beijing's Tiananmen Square, Moscow's Leningrad or Cairo's Tahrir Square. Whilst the origin of Tundikhel's political role links back to the Rana era, most explicit recognition came with the establishment of Khula Manch in 1962, fashioned somewhat in the Speaker's Corner in Hyde Park. Draped in the guise of space for cultural performance, the space soon achieved an iconic status as the first site for any anti-establishment demonstrations in Kathmandu despite that space was argued to have been designed to curb dissent (Sengupta 2018).

Nepal's civil war began on 13 February 1996, with a series of attacks by Maoists on several police posts and a formal declaration of a 'people's war'. Up until the turn of the century, Maoists remained completely underground, and the war was fought high up in the mountains or in the interiors of the forests. The 'anti-regression' demonstrations in Kathmandu organized by five political parties in April 2004 sympathizing with the Maoist cause brought the clandestine Maoist operations into the streets of Kathmandu, frequently originating from Tundikhel. Throughout the latter part of the civil war period, the country witnessed Tundikhel as the material location for political activities and sites for protests and dharnas. What ensued was a cycle of demonstrations occurring in Tundikhel and public spaces of Kathmandu and authorities putting restrictions turning this into a struggle for space. Access to Khula Manch in Tundikhel was frequently restricted. The political movement, in the 1990s that coincided with televisions being more prevalent, helped to transmit Tundikhel's powerful imagery across the globe as the space facilitating the democracy movement in Nepal. With the ubiquitous media presence capturing the political struggle transmitting images and actions, Tundikhel's visual and metaphorical appeal effectively reached the world stage.

The civil war was not just the Maoists' struggle for change but the society's response to the exclusionary process of class formation instituted by the imperialism of the 'Royals.' Such response required a space of distinction which would match the scale of political and democratic ambition. Tundikhel's historical significance as a mystical urban park, a cosmological shunya sthan, a national cultural space, and a parade ground have provided building blocks to elevating it as a crucial material space serving the aim of nation-building and the maintenance of political legitimacy. The ensuing political upheaval and struggle for power culminated in the dissolution of the monarchy on 28 May 2008, with King Gyanendra agreeing to step down to pave the way for setting up the democratic republic of Nepal. The celebration of democracy, yet again, originated in Tundikhel.

Paradoxically, however, at the very moment in which the historical symbolism appears to have acquired an unprecedented strategic significance for an extraordinarily broad array of institutions, organizations, and users its definitional contours have become unmanageably slippery. In the last few years, and especially since the abolition of the monarchy, Tundikhel has witnessed an emergence of public space politics, driven partly by a rediscovery of its historical meanings and functions. A constellation of primarily three forces - institutional, military and informal insurgency - is currently evident, competing to establish their sovereign rights to occupy and govern this space. Increasing contestation for the space has led to what Sengupta (2018:2795) calls "urban rupturing," a process of (un)making of public space, through physical and symbolic fragmentation and spatial estrangement. Demonstrations under the banner of Occupy Tundikhel backed up by a series of parallel events, such as the Ranipokhari Bachao and Free Khula Manch have erupted, which resonate with the anti-establishment struggles witnessed through Occupy Wall Street and Occupy Tahrir Square. The contexts of these various protests are very different, and they are not simply iterations of what happened elsewhere. Rather, the Occupy Tundikhel movement has managed to touch the important chords of heritage and public memory framed in the nationalist as well ethnic sentiments linked to the medieval era, that the indigenous Newar culture is rooted to. Tundikhel is unique in that the recent struggle witnessed through Occupy Tundikhel movement relates to preserving the integrity of this space as opposed to those squares, such as Tahirr Square or Tiananmen Square which act just as the means to one end. "Let Tundikhel be what Tundikhel was," ran the headline in National Daily Nepali Times (Chitrakar, 2019), which reveals the overwhelming sense of public space as a symbol of history being subject to distortion. The distortion related to memory and history is as much about facts or interpretations, as it is of distortion from the lack of congruity between personal experience and expectation, on the one hand, and the institutional representation of the past on the other. The new 'nationalist sentiment' has materialized by evoking the appealings to the 'indigenous' medieval roots regarded widely as the 'Golden Age' in the nation's history (Onta, 1993). However, pursuits of the 
erasure of the symbolisms from one past to reinstate those from another remains incomplete and contested. This links back to Rapoport (1977: 34), who argues that most urban environments are too large to be seen or captured as one, which makes memory and inferences essential. Any mental construct is followed by perception, cognition, and evaluation. The process occurs over time and cognitions are built up gradually, from direct and indirect experience, whereas perceptions are more instantaneous. This introduces a plurality of notions of space. Tundikhel might be a single space in rhetoric, in perception, we are starting see multitude of fragmented interpretations.

The fact that different groups view Tundikhel as a cultural artifact within intricate power geometries refutes the notion that the space has a single meaning, on the contrary, it often contains competing or hidden messages and symbols differentially interpreted by different groups. To the authorities, the space is not just the expression of power, but also the means through which power is manifested and maintained. To the citizens, space presents opportunity to bridge particular distances and when they hope to establish new coalitions and political agendas by challenging agreed upon distances. Tundikhel then becomes decidedly a conceptual entity in that it symbolizes the attitudes and aspirations of a diverse culture bearing contradictions not just in space but of space (Lefebvre 1991).

The struggle between different elements of the city to manipulate its politics and control which has left deep imprints on the ground. Barbed wires, high iron gates, army patrols and municipal wardens in Tundikhel create boundaries and prevent access. The cycle of hasty construction (in Khula Manch) and demolitions have followed in recent years by the Municipality which has further erased public access and impacted the openness of the space significantly altering it constitution. the Municipal actions ignore, yet another important dimension of Tundikhel: its ownership. The Guthi offcials ${ }^{16}$ claim that up to $2 / 3$ rds of Tundikhel land is Guthi-owned. Guthis are lands held in public trust. This leads to an argument that the current occupation of the space either by the army or by the municipality may not be grounded in law and that the battle may be more a mental construct.

No doubt the extent of the contestation currently being observed and the control exerted are both reflective of the power politics that encapsulates the city's increasingly fluid political situation today. The emergent process is however producing variegated effects on Tundikhel that is suggestive of the historic symbolisms now woven unevenly albeit more densely. This unevenness is starting to become incongruous with the social and cultural reorientations of the city to the extent that the publicness of the space is beginning to erode. On the other hand, it risks detaching Tundikhel from the 'main' city (the historic and the modern), both physically and materially.

\section{Conclusion}

Through historical antecedents, the preceding sections showed how public space bears a testimony of resilience and adaptability arising from the prevailing religious, social, and political context of the city during different phases of history. Plausible arguments can, therefore, be made to show how Rapoport's three levels of meaning come into interplay across different periods with varied spatial manifestations. The establishment of temples at Tundikhel during the early Licchabi period is suggestive of the cosmological and symbolic significance of the space which was crystallized through mandala planning and layout during the medieval period. Tundikhel's role as a site for the military display of power and pride became prominent during Shah and Rana period, which reaffirmed the supremacy of the rulers, thus assigning Rapoport's middle-level meaning. And finally, Tundikhel's role as democracy's battleground to attain freedom and emancipation at the turn of the century is perhaps suggestive of a low-level meaning. Put differently, the multiple meanings and interpretations defines the space as an object with wider cultural-political discourses. In architecture, images represent memory and this has become dominant in how we read and interpret a place. Space thus cuts different spatial, social, and temporal orders which are different, but related. And, these orders rely on the same process of observing memory, identity, location, and orientation or value position.

Notwithstanding the very real and important differences within cosmological, mercantile, or the political symbolisms, all three symbolisms show a common set of behaviorial and built-environmental mechanisms that underlie conceptual, economic, and political drivers normally discussed in the urban literature. Cities are a place of "energized crowding" Kostof (1991: 31) claims, which transmits onto public space in various forms. These underlying mechanisms have been explored in this paper that are embedded in physical space taking a perspective which is both theoretically grounded and empirically supported. It must be recognized that the space called Tundikhel has been the one where wider sociocultural discourses, institutions, norms, and practices were reproduced and, on occasion, transformed. 
Thinking of Tundikhel today as a post-modern, hybrid public space does more to capture the nature of the city's change as a complex, multi-layered shift in which the history cannot be simply erased, but returns to disrupt contemporary narratives of the national space. The evolution of Tundikhel is, however, far from finished. As society progresses, new ways of the art of articulating space evolve. Tundikhel, as it exists today, is not just a picture of the present situation; it is, therefore, a link between a city of antiquity with its success and failure and a city of posterity with its hope and aspiration.

The prospect of the city and its space can, therefore, be largely determined by examining the value system of each period, values attached to the built environment at each period and its impact on city metabolism. Rapoport's (1977) considers people's expectations and how they remember what they experienced as paramount in understanding space and cities. It involves a process of coding or categorization that helps memory, which also seems to be a function of expectations. Applying to the long history of the space, this suggests two things: that memory that is the incorporation in cognitive schemata is selective and involves some preferences and, second that symbolic aspect, and hence imagery may be important (ibid: 35 ). The future is not written yet, so it is up to us whether we erase memories, space, and destroy historical sites such as Tundikhel or we preserve it and enhance its value. Despite shifting meanings and functions, Tundikhel has remained a quintessential public space of heritage sensitivity that needs recognition in planning, design, and city development processes.
Dr Urmi Sengupta has an interdisciplinary background in Architecture, Planning and Urban Design. Her recent research has focused on the politics of public space, postdisaster reconstruction, aesthetics, equity and social justice. She sits on the editorial boards of leading journals and advisory boards of NGOs in Nepal and India. She is currently affiliated with Queen's University Belfast.

The research was funded by the British Academy/ The Leverhulme Trust and Sir Ernest Cassel Educational Trust Fund (Grant No.: SG133061). The author would also like to thank the anonymous reviewers for their comments on the earlier drafts of the paper. The views expressed here are those of the author.

\section{Endnotes}

1. For a detailed account on how three dominant modalities of power have collided in Tundikhel, see Sengupta (2018).

2. There has been limited but growing body of literature written on the historic built form of the Valley. They are from both local and international scholars and although gaps exist, provide a consistent view on how the built form and spaces evolved; See Amatya, Archaeological \& Cultural Heritages; Amatya, Art and Culture of Nepal; Levy, Mesocosm Pant and Funo, The Grid and Modular. Also see Slusser, Nepal Mandala; Stoddard, Perception about; Tiwari, The Ancient Settlements; Tiwari, The Brick and the Bulland Gustchow, and Bajracharya, Ritual as a Mediator, 1-10.

3. Levi (1905) argued that the progressive Hinduization of an ethnically and culturally diverse population by the dominant Indo-Nepalese, and the conflicting trends towards amalgamation and disintegration of smaller political units within the Himalayan foothills can both aid our understanding of what happened on a larger scale throughout South Asia generally.

4. Three key authors stand out: Rapoport (1990) The Meaning of the Built Environment; Lynch (1981), A Theory of Good City Form; and Smith (2007), Form and Meaning in the Earliest Cities.

5. Shilparatna was the Indian classical text for art composed in the $16^{\text {th }}$ Century.

6. Singh, in his book Cities and Parks in Ancient India is based on the ancient scriptures. Though not much anecdotal evidence exists, in the Ancient Hindu epics of Mahabharata or Ramayana, we find frequent mention of nagaropavnas used for recreational and festive activities. According to Ramayana, Ayodhya had many parks. It also includes an extended illustration of Asokvatika, the 
enchanting garden where Sita was kept captive for several years. Likewise, it is said that Lumbini - the birthplace of Buddha - had many public parks and gardens.

7. The Digha Nikaya is a Buddhist scripture, the first of the five nikayas, or collections, in the Sutta Pitaka, which is one of the 'three baskets' that compose the Pali Tipitaka of (Theravada) Buddhism.

8. A text written by Pundit Sundaranada Banda in the $1^{\text {st }}$ half of $19^{\text {th }}$ century is a formidable historical record on different aspects of Nepal in the centuries immediately preceding it.

9. Does this mean the dwellings near Tundikhel were predominantly occupied by lower castes given that the interface of Tundikhel points to the end of the city limit? This assumption would relegate Tundikhel's location in the spatial order to the periphery, a location of subdued importance relative to the central areas in Mandala terms.

10. Oldfield was a Surgeon who lived in Nepal between 1850 and 1864. During his stay, he produced over 200 hundred drawings and watercolor paintings and wrote detailed accounts of the geography, history, religion, and architecture of the country, later published as Sketches from Nepal. According to him Newari towns and cities typically were defined as walled cities with numerous walls punctured with gates opening up to something significant. The native cultures and customs provide numerous nomenclatures to these gates and walls and cultural practices that still exist today. Several urban spaces are still known by the names of these gates according to the Newari tradition.

11. Shrestha and Singh (1971) in The History of Ancient and Medieval Nepal, assert Amshuvarma by his clever stroke of diplomacy maintained the balance of power and kept his sovereignty intact. He contracted matrimonial alliance with Tibet by giving his daughter Bhrikuti in marriage to Tsrong Tsong Gyampo. Bhrikuti exercised her good offices in spreading Buddhism in Tibet. Because of her efforts, Buddhism took its root in Tibet (ibid: 13).

12. The origin of Rani Pokhari is not without contradictions. Clark (1957) has undertaken a detailed study of stone inscriptions in Rani Pokhari and Hanuman Dhoka to arrive at two sets of conjectures, one- the pond built by the Queen in memory of her son Chakrabartendra Malla who died within 24 hours of attaining the throne; two- the pond was built by Pratap Malla in memory of his third queen who died prematurely. Both conjectures imply association with some queen, which gives its name. An elephant carrying three persons believed to be the king, queen and the deceased son stands even today. During
Pratap Malla's reign for thirty years (1641-1674), Nepalese art and architecture reached its height (ibid: 177).

13. See Sengupta (2018) for details.

14. Between 1769 and 1846, the Shah dynasty was embroiled in a protracted power struggle that culminated in the faustian agreement which led to the emergence of Rana regime in 1846. For more than a century, Nepal was under the rule of autocratic Rana rulers with the Shah Kings as dejure heads and Rana Prime Ministers as the defacto rulers. During the Rana regime, some isolated efforts were made to bring about progressive political and social changes, but they represent a regressive rule. They were eventually overthrown by the joint efforts of the Shah king Tribhuwan and the people in 1951, heralding the emergence of modern Nepal.

15. The original structure of Ghantaghar was destroyed during 1934 earthquake and was later rebuilt with a simplified design without the arches. In the process, one of the largest bells was taken away and not restored.

16. Guthi Sansthan is a government organisation with consolidated powers to manage thousands of Guthis (community-owned assets) across the country. It represents a centralized governance that was part of modernization programme in order to make Guthis more efficient and productive given the diversity of practices. Across the country Guthi lands, estimated at 140 thousand Ropanis, function as a trust and are usually associated with religious practices.

\section{References}

Amatya, S. 2011. Archaeological \& Cultural Heritages of Kathmandu Valley. Kathmandu: Ratna Pustak Bhandar.

1991. Art and Culture of Nepal: An Attempt Towards Preservation. Jaipur: Niral Publications.

1996. Landmarks in Tundikhel. Kathmandu: Ratna Pustak Bhandar.

Anderson, B. 2006. Imagined Communities. London \& New York: Verso.

Aranha, J. L. 1991. A comparison of Traditional settlements in Nepal and Bali. Traditional Dwellings and Settlements Review (11): 35-47.

Bajracharya, D. 1973. Licchavikālakā Abhilekha. Kiritipur: Institure of Nepal and Asian Studies. 
Bell, J. 1999. Redefining National Identity in Uzbekistan: Symbolic Tensions in Tashkent's Official Public Landscape. Ecumene, 6(2): 184-213.

Chitrakar, A. 2019. 'Let Tundikhel be what Tundikhel was', Nepalitimes, 11 December.

de Certeau, M. 1984. The Practice of Everyday Life. Berkeley: University of California Press.

Deo, S. B. 1968. Archaeological Excavations in Kathmandu, Kathmandu: His Majesty's Government of Nepal.

Dovey, K. 2001. Memory, democracy and urban space: Bangkok's path to democracy. Journal of Urban Design 6 (3): 265-282.

Ethington, P. J. 2007. Placing the Past: 'Groundwork' for a Spatial Theory of History. Rethinking History 11(4): 465-94.

Frechette, A. 2004. Tibetians in Nepal: The Dynamics of International Assistance among a community in exile. Canada: Berghahn Books.

Gabriele, V. 1997. The Design of the City: Urban Space in the Kathmandu Valley. Spazio eSocieta(75): 32-37.

Gutschow N and Kreutzmann, H. 2013. Mapping the Kathmandu Valley with Aerial Photographs by Erwin Schneider. Kathmandu: Himal Books.

Gustchow, N. and Bajracharya, M. 1977. Ritual as a Mediator of Space in Kathmandu. Journal of the Nepal Research Centre, 1: 1-10.

Gramsci, A.1971. Selections from the Prison Notebooks. London: Lawrence \& Wishart.

Holloway, J. 2006. Enchanted Spaces: The Séance, Affect, and Geographies of Religion, Annals of the Association of American Geographers, 96(1): 182-187.

Johnson, N. 2013. Public memory. In James S. Duncan Nuala C. Johnson Richard H. Schein A (eds), Companion to Cultural Geography, 316-327, Oxford: Blackwell Publishing.

Kostof, S. 1999. The City Shaped: Urban Patterns and Meanings through History. London: Thames \& Hudson Limited.

Lefebvre, H. 1991. The Production of Space. Oxford: Blackwell Publishers.

Lewis T. T. 1989. Newars and Tibetans in the Kathmandu Valley, Journal fo Asian and African Studies (38): 31-57.

Levy, Robert I. 1990. Mesocosm. Hinduism and the Organization of a Traditional Newar City of Nepal. Delhi: Motilal Banarsidass.
Levi, S. 1805. Le Nepal Vol 1, Paris: ErnestLeroux,. Translated in English by Theodore Ricardii Jr.

Light, D. and Young, C. 2010. Political Identity, Public Memory and Urban Space: A Case Study of "Parcul Carol I," Bucharest from 1906 to the Present, 62(9): 1453-1478.

Lynch, K. 1981. A theory of good city form. Cambridge, MA: MIT Press.

Maharjan, H. M. 2010. Machinery of state Control: History of Cinema censor board in Nepal." BODHI-An Interdisciplinary Journal, 4(1): 168-190.

Malla, K. P. 1975. Linguistic Archaeology of the Nepal Valley: A preliminary report", Kailash, 16(1): 5-23.

MacFadyen, T and Vogt, W 1977. The city is a mandala: Bhaktapur, Ekistics, 44 (265): 307-309-1489.

Mitchell, M. 2000. Cultural Geography. A Critical Introduction. Oxford: Blackwell.

Oldfield, H. A. 1974. Sketches from Nepal. Delhi: Cosmo Publication.

Onta, P. 1993. Whatever Happened to the "Golden Age"?, Himal, Jul 01.(Available at: https://www.himalmag.com/ whatever-happened-to-the/ (last accessed date: 6 August 2021)

Pant M. and Funo, S. 2007. Stupa and Swastika: A Study on the Planning Principles of Patan, Kathmandu Valley, Singapore: NUS Press.

Pant, M. and Funo, S. 2005. The Grid and Modular Measures in The Town Planning of Mohenjodaro and Kathmandu Valley, Journal of Asian Architecture and Building Engineering 4(1): 51-59.

Rapoport, A. 1990. The Meaning of the Built Environment: A Nonverbal Communication Approach, Tucson: University of Arizona Press.

Rapoport, A. 1977. Human Aspects of Urban Form: Towards a Man-Environment Approach to Urban Form and Design. New York: Pergamon Press.

Rapoport, A. 1970. The Study of Spatial Quality. The Journal of Aesthetic Education 4(4): 81-95.

Regmi D. R. 1965. Ancient and Medieval Nepal, Fir.ma K. H. Mukhopadhyay: Calcutta.

Regmi, M. C. 1982. Cumulative Index for 1982, Kathmandu: Regmi Research Centre. 
Routledge, P. 1994. Backstreets, barricades, and blackouts: Urban terrains of resistance in Nepal. Environment and Planning D: Society and Space 12: 559-578.

Sengupta, U. 2018. Ruptured space and spatial estrangement: (Un)making of public space in Kathmandu. Urban Studies 55 (12): 2780-2800.

Sengupta, U., \& Bhattarai Upadhyay, V. 2016. Lost in Transition? Emerging forms of residential architecture in Kathmandu. Cities 52: 94-102.

Sharma, D. R. 1996. A note on the historical and Cultural significance of Vajrayogini of Sankhu. CNAS Journal/TU 23 (1).

Singh, R. B. 1976. Cities and Parks in Ancient India. Ekistics, 43(243): 372-376.

Slusser, M. 1982. Nepal Mandala: A Cultural Study of the Kathmandu Valley. Princeton, NJ: Princeton University Press.

Shrestha, D.B and Singh, C.B. 1971. The History of Ancient and Medieval Nepal in a nutshell with some comparative traces of Foreign History. Nepal: His Majesty Government (HMG).

Smith, M. E. 2007.Form and Meaning in the earliest cities: A new approach to ancient urban planning. Journal of Planning History 6(1): 3-47.

Soja, E.W. 1995. Heterotopologies: A Remembrance of Other Spaces in the Citadel-LA. In Postmodern Cities and Spaces edited by S. Watson \& K. Gibson (13-34). Cambridge: Blackwell.
Stoddard, R. H. 1979. Perception about the geography of religious sites in the Kathmandu Valley." Contributions to Nepalese Studies. 7(1\&2): 97-118.

Till, K. E. 2004. The New Berlin: Memory, Politics, Place. Minneapolis, MN: University of Minnesota Press.

Tiwari, S. R. 2001. The Ancient Settlements of the Kathmandu Valley. Kathmandu: Centre for Nepal and Asian Studies.

Tiwari, S. R. 2002. The Brick and the Bull: An Account of Handigaun, the Ancient Capital of Nepal". Kathmandu: Centre for Nepal and Asian Studies, Tribhuvan University.

Tiwari, S R, Shrestha, P, Bjønness C. H. 2018. Local Rights in World Heritage Sites: Learning from Post-Earthquake Rehabilitation Dynamics in the Kathmandu Valley. In World Heritage and Human Rights. Lessons from the Asia Pacific and the Global Arena. Edited by Bille Larsen Peter.

Toffin, G. 1990. Mythical and symbolic origins of the city: The case of the Kathmandu Valley, Dio- genes (Engl. ed.), SAGE Publications:101-123.

Tuan, Yi-fu. 1977. Space and Place: The Perspective of Experience. Minneapolis: University. of Minnesota Press.

UNESCO. 1997, Changing Faces of Nepal: the Glory of Asia's Past. UNESCO: Himal Asia.

Whelan, Y. 2001. Monuments, Power and Contested Space?The Iconography of Sackville Street (O'Connell Street) before Independence (1922)', Irish Geography, 34(1): 11-33.

Whitmarsh, B. 2019. Ganatantra Smarak: The Politics of Memory. Studies in Nepali History and Society 24(1): 171-216. 